\title{
KONFLIK ARMENIA DAN AZERBAIJAN DALAM PEREBUTAN WILAYAH NAGORNO KARABAKH MENYEBABKAN KRISIS BERLARUT LARUT
}

\author{
Sulthan Farhan Praestu \\ Program Studi Pendidikan Sejarah, Fakultas Ilmu Sosial, Universitas Negeri Malang \\ Jalan Semarang No.5, Malang 65145 \\ E-mail: Sulthanpraes31@gmail.com
}

\begin{abstract}
ABSTRAK
Konflik dalam perebutan wilayah Nagorno karabakh sudah terjadi mulai abad ke 20. Secara Resmi wilayah tersebut diakui oleh Azerbaijan namun secara etnis wilayah tesebut mayoritas etnis Armenia.Hubungan kedua belah pihak mulai tegang setelah pada tahun 1994 kedua belah pihak saling melakukan genjatan senjata.pada peristiwa tersebut banyak terjadi krisis dan pelanggaran ham yang menyebabkan penderitaan yang berlarut larut.Dalam penelitian ini membahas dan menyelesaika konflik azerbaijan dan Armenia.Dalam permasalahan tersebut perlu adanya pemangku kepentingan (PBB) dalam menegakkan hukum internasional guna untuk mewujudkan masyarakat yang beradab bebas konflik
\end{abstract}

Kata Kunci: Konflik,Etnis, Wilayah

\begin{abstract}
Conflict in the territorial struggle for Nagorno Karabakh has occurred since the 20th century. Officially the territory is recognized by Azerbaijan, but ethnically the area is ethnic Armenian. Relations between the two sides began after in 1994 the two sides held a mutual ceasefire. many have happened and human rights conflicts that have caused prolonged suffering. In this study discusses and resolves the conflicts of Azerbaijan and Armenia. In this problem it is necessary to have stakeholders (UN) in upholding international law in order to create a civilized society free of conflict
\end{abstract}

Keywords: Conflict, Ethnicity, Territory

\section{Pendahuluan}

Pada wilayah kakaus selatan terdapat dua kawasan kecil yang bernama nagorno dan karabhak. Kedua wilayah tersebut merupakan wilayah yang strategis yang menghubungkan kawasan timur tengah ,asia dan eropa timur.Wilayah Nagaro karabak secara internasional berada diwilayah Azerbaijan namun mayoritas yang menghuni adalah Etnik Armenia. Pada saat itu wilayah tersebut masih berada dibawah naungan unisoviet membuat ketengangan kedua belah pihak masih bisa diredam.Namun saat kepemimpinan Gorbacev ia membebaskan wilayah unisoviet untuk menentukan masa depannya sendiri yang disebut glasnot dan perestorika.Dalam kebijakan tersebut membuat adanya ketegangan kembali karena Armenia menganggap bahwa wilayah tersebut masih berada pada wilayahnya namun ditentang oleh Azerbajian.

Sejak Gorbacev memimpin unisoviet lambat laun mengalami keruntuhan Dengan pecahnya Uni Soviet pada akhir tahun 1991, baik Azerbaijan maupun Armenia merdeka dan tanggung jawab Moskow untuk mengelola dan menangani konflik NagornoKarabakh tiba-tiba menghilang. Dalam 
beberapa bulan, konflik berubah menjadi perang skala penuh, yang melibatkan pasukan reguler Armenia dan seluruh bekas detasemen militer Soviet di bagian Karabakh Armenia. lingkungan, sebelumnya dihuni oleh suku Azeri yang homogen. Secara total, lebih dari $20 \%$ wilayah negara masih diduduki. Sejak awal konflik 1988, lebih dari satu juta Azeri terpaksa mengungsi dari rumah mereka di Armenia, Karabakh, atau daerah sekitarnya.

Namun, sejak saat itu pada awal tahun 1992, konflik juga memiliki dimensi antar negara dalam arti terlibat dua negara berdaulat yang berperang: Armenia dan Azerbaijan. Ada tiga pertandingan kandang konflik, yaitu pemerintah dua negara berdaulat, serta pemerintah yang tidak diakui "Republik Nagorno-Karabakh" adalah salah satu faktor yang menawarkan solusi terbesar untuk konflik tersebut. Konflik telah menjadi salah satu kontroversi tersulit di dunia . Karena itu satu-satunya dari berbagai konflik etnopolitik di Kaukasus dengan dua negara yang diakui secara internasional sebagai pihak, ini juga merupakan konflik di lapangan memiliki kepentingan geopolitik terbesar. (Cornel,1999)

Pada awal 1988, konflik terus berlanjut di antara negara-negara Kaukasus Selatan Azerbaijan dan Armenia untuk wilayah Nagorno Karabakh yang disengketakan. Konflik tersebut diakibatkan selain dua puluh ribu korban dan hampir satu setengah juta pengungsi, satu pengungsi aliran yang menyebabkan krisis yang cukup besar, terutama di Azerbaijan, dengan jumlah tersebut ada sekitar satu juta pengungsi.(Cornell,1999)

\section{Pembahasan}

Ketika Trans Kaukasus dimasukkan ke dalam Kekaisaran Soviet pada 1920-21, perbatasan antara Azerbaijan, Armenia dan Republik Georgia tidak segera ditentukan. Ini terutama karena masalah mempersempit batas antara Armenia dan Azerbaijan, terutama wilayah Nagorno-Karabakh dan Nakhichevan. Periode ini ditandai dengan perjuangan politik melawan Karabakh antara Armenia dan Azerbaijan di Uni Soviet, yang memakan waktu lama karena kepemimpinan Soviet membutuhkan waktu tiga tahun untuk menyelesaikan masalah tersebut.Pendulum tersebut tampaknya menerima dukungan Armenia ketika Komisi Revolusi Azerbaijan Soviet mengeluarkan deklarasi pada Desember 1920 (di bawah tekanan Soviet) bahwa Karabakh, Zangezur, dan Nakhichevan dipindahkan ke kendali Armenia. Stalin (kemudian direktur kewarganegaraan) mengumumkan keputusan itu pada 2 Desember, tetapi pemimpin Azerbaijan $\mathrm{Na}$ Limanov kemudian menolak langkah tersebut. (Cornell, 1997)

Bahkan dalam menghadapi kecenderungan Stalin untuk memecah belah Kaukasia untuk menghindari perlawanan kesatuan, dua gagasan untuk membagi orang Armenia menjadi dua unit - Republik Armenia dan Nagorno-Karabakh - pasti diterima. Selain itu, Stalin berhasil membagi tidak hanya Armenia, tetapi juga Azerbaijan menjadi republik Azerbaijan dan Nakhchivan (meskipun yang terakhir terus menjadi bagian administratif dari SSR Azerbaijan). Alasan lain mengapa pemerintah Soviet mendukung Azerbaijan sangat berkaitan dengan cara ideologi Bolshevik diterima di Kaukasus. Faktanya, Armenia tidak menunjukkan kecenderungan komunis yang dapat disebutkan selama tahun-tahun revolusi dan perang saudara. Di Armenia, partai Dashnak merupakan kelompok politik yang dominan selama periode tersebut. Jauh dari berorientasi pada ide-ide sosialis, Dashnak adalah gerakan nasionalis Armenia yang kuat. Ini diilustrasikan oleh fakta bahwa Dashnak tetap berkuasa di Zangezur hingga 1921, menolak pemerintahan Bolshevik sementara Yerevan jatuh di bawah kekuasaan komunis. Sebaliknya, ada dukungan populer untuk ideologi Bolshevik. (Cornell, 1997). 
Jurnal Sosial Humaniora Sigli (JSH)

p ISSN : 2615-3688

$e$ ISSN : 2716-0270

http://journal.unigha.ac.id/index.php/JSH

Konflik antara Armenia dan Azerbaijan dimulai pada abad ke-20 atau akhir 1980-an, dan konflik tersebut muncul karena sengketa wilayah antara Armenia dan Azerbaijan. Masalah ini muncul sebagai akibat dari runtuhnya Uni Soviet. Proses runtuhnya Uni Soviet membawa orangorang non-Rusia sebagian berdaulat dan berada di puncak penyerahan diri dan membuat kedaulatan hingga merdeka Kemerdekaan, runtuhnya Uni Soviet, dan tatanan dunia terpecah di wilayah hubungan internasional selama Perang Dingin. Konflik Nagorno-Karabakh adalah konflik besar pertama dan paling rumit konflik pascaSoviet dan sebenarnya dimulai tiga tahun sebelum bentrokan dari Uni Soviet ketika Daerah Otonomi Nagorno-Karabakh mendeklarasikan kemerdekaan Azerbaijan untuk bergabung dengan Armenia.26 Demonstrasi penyatuan Nagorno-Karabakh dengan Armenia dimulai pada tahun 1987, ketika petisi, yang ditandatangani oleh lebih dari 75.000 orang Armenia, diserahkan kepada Mikhail Gorbachev. Acara ini menginspirasi anggota Armenia NagornoPada 20 Februari, parlemen Karabakh memberikan suara untuk menyatukan wilayah tersebut dengan Armenia 1988. Keputusan ini memicu serangan kekerasan terhadap populasi minoritas a Armenia dan Azerbaijan, dan sejumlah besar pengungsi, melarikan diri dari kedua negara tersebut. Setelah referendum disetujui untuk pelatihan independen negara pada bulan Desember 1991, perang skala penuh dimulai antara kedua belah pihak. Di Selama tiga tahun, pasukan Armenia menduduki seluruh Nagorno-Karabakh dan distrik sekitar Azerbaijan membangun peredam wilayah dan pengaruh yang akan digunakan selama negosiasi perdamaian(Ozkan,2008)

Sejak awal 1988, telah terjadi konflik antara Azerbaijan dan Republik Transkaukasia Armenia di wilayah Nagorno-Karabakh. Konflik tersebut mengakibatkan krisis pengungsi yang relatif serius, terutama di Azerbaijan, dengan lebih dari satu juta orang. Pembersihan rasial skala besar dan pelanggaran hak asasi manusia telah dilaporkan di daerah di mana $20 \%$ dari wilayah republik diduduki dan dikendalikan oleh apa yang oleh "komunitas internasional" disebutArmenia sangat menderita akibat blokade Azerbaijan yang dimulai dari pintu masuk Turki, menyebabkan kekurangan energi yang serius.Azerbaijan sejauh ini belum mampu menormalisasi perekonomian nasionalnya dengan sumber minyak dan gas yang melimpah. (Cornell, 1997)

Selama konflik dan hingga saat ini Azerbaijan diisolasi secara internasional karena beberapa alasan. Baik Amerika Serikat maupun Rusia telah menjalankan kebijakan dalam konflik yang cenderung ke Armenia; Iran juga, bahkan jika itu adalah negara Islam dan denominasi Syiah seperti Azeri.Satu-satunya negara yang secara konsisten menyatakan dukungannya kepada Azerbaijan adalah Turki. Di semua forum internasional, Turki telah mencoba menjelaskan dan mempromosikan pandangan Azerbaijan tentang konflik tersebut dan tentunya berperan dalam mencegah pendekatan pro-Armenia yang mendominasi forum.Selanjutnya, Turki dan Azerbaijan telah bersama-sama mengembargo Armenia dan Turki menolak untuk menormalisasi hubungan dengan Armenia selama Armenia telah menduduki wilayah-wilayah pendudukan di Azerbaijan. Namun, terlepas dari dukungannya untuk tujuan Azerbaijan, Turki telah berhenti memberikan Azerbaijan senjata atau bantuan keuangan apa pun yang mungkin diizinkan untuk dibeli; Selain itu, Turki tidak pernah mengancamDi sini kami mencoba menilai kebijakan Turki dalam konflik dan menganalisis faktor-faktor yang membatasi Turki dan mencegahnya untuk menjalankan kebijakan yang benar-benar independen dalam sengketa tersebut. (Cornell,1998)

Sampai saat ini, tampaknya tidak ada perubahan posisi komunitas internasional 
dalam konflik Nagorno-Karabakh. Secara umum, kurangnya minat opini publik dunia di Kaukasus secara umum telah diperjelas dengan invasi berdarah Rusia ke Chechnya pada awal 1995. Pelanggaran hak asasi manusia yang dilakukan di sana belum dibahas; tetapi juga tanggapan diam-diam dunia Barat terhadap berbagai peristiwa hanya menegaskan ditinggalkannya "Komunitas Dunia" .Satu-satunya kesimpulan yang dapat ditarik dari analisis kami adalah bahwa adalah kebenaran yang menyedihkan bahwa prinsip-prinsip hukum, terutama di tingkat internasional, diterapkan dengan pertimbangan kekuasaan dan kebutuhan, bukan dengan prinsip persamaan dan keadilan. (Cornell, 1997)

\section{Penutup}

Pada Perebutan wilayah tersebut terjadi banyak krisis terutama pada krisis kemanusian karena dalam perang tersebut tidak hanya satu negara yang berperan tapi banyak negara yang berperan.Banyak korban yang berjatuhan serta kerugian yang ditanggung oleh kedua belah pihak tidaklah
sedikit.Dan masih kurangnya minat opini publik terhadap pertikaian antara kedua belah pihak .Seharusnya hukum hukum internasional harus diterapkan sesuai dengan prinsip persamaan dan keadilan.

\section{Referensi}

Cornell, S. E. (1997). Undeclared War: The Nagorno-Karabakh Conflict Reconsidered. Journal of South Asian and Middle Eastern Studies, 20, 1-23.

Cornell, S. E. (1998). Turkey and the conflict in Nagorno Karabakh: a delicate balance. Middle Eastern Studies, 34(1), 51-72.

Cornell, S. E. (1999). The NagornoKarabakh Conflict. Uppsala Universitet.

Özkan, B. (2008). Who gains from the "no war no peace" situation? A critical analysis of the Nagorno-Karabakh conflict. Geopolitics, 13(3), 572-599. 